\title{
A Hybrid Steelworks Combining Manufacturing and Energy Supply
}

\author{
Tsuguhiko NAKAGAWA* \\ Department of Thermal Engineering, Graduate School of Okayama Prefectural University, Kuboki 111, Soja, Okayama, 719- \\ 1197 Japan.
}

(Received on May 4, 2014; accepted on May 29, 2014)

\begin{abstract}
Japanese steelworks achieve the world's highest energy efficiency. However, approaches that seek intra-steelworks optimization alone have limitations when planning further energy conservation. It is thus necessary to establish a system that effectively utilizes energy at the societal level.

This study is proposed a hybrid steelworks having functionality that combines steel manufacturing and energy supply, focusing on improving the energy utilization of by-product gas. As the results, the typical hybrid steelworks is able to supply society with low-cost electric power without increasing energy consumption through the use of combined high-efficiency GTCC with the promotions of energy conservation in steelworks such as $\mathrm{CO}_{2}$ and $\mathrm{N}_{2}$ separation in blast furnace gas. Moreover, if the technology of this hybrid steelworks is applied to all steelworks in Japan (84 million t-steel/year blast furnace crude steel), the power generation potential is more than 38 billion $\mathrm{kWh} /$ year which is equivalent to $4.0 \%$ of gross domestic power demand. Furthermore, a $\mathrm{CO}_{2}$ reduction of 33 million $\mathrm{t}-\mathrm{CO}_{2} /$ year nationally can be expected; this effect is equivalent to a $23 \%$ reduction in steelworks $\mathrm{CO}_{2}$ emissions.
\end{abstract}

KEY WORDS: hybrid steelworks; $\mathrm{CO}_{2}$ emission; gas turbine combined cycle; gas separation; blast furnace gas; power generation efficiency.

\section{Introduction}

The Japanese government has lowered its $\mathrm{CO}_{2}$ emissions reduction target in November 2013, announcing a new target from 2005 levels by 2020. In the meantime, the 2013 trade deficit 2013 enlarged to 13.7 trillion yen, with total fossil fuel imports reaching 28.4 trillion yen out of 84.6 trillion yen total imports. These values indicate the need as a nation to reduce energy imports not only from a $\mathrm{CO}_{2}$ emissions standpoint, but also from an economic one. ${ }^{1)}$

Not just the introduction of renewable energy, but improvement in energy utilization rate across the country is crucial to reducing energy imports. In fact, Japanese steelworks have maximized energy utilization, and have achieved the highest energy conservation rates in the world. However, optimization of steelworks alone to plan further energy conservation is a limited approach; building a new system for the effective utilization of energy is necessary for society as a whole. ${ }^{2}$

This study is proposed a hybrid steelworks with functionality that combines steel manufacturing and energy supply based on the energy balance of steelworks and with a focus on improving the energy utilization of by-product gases. We then examine the reduction effects on energy and $\mathrm{CO}_{2}$ emissions in a society with hybrid steelworks.

\footnotetext{
* Corresponding author: E-mail: nakagawa@cse.oka-pu.ac.jp DOI: http://dx.doi.org/10.2355/isijinternational.55.373
}

\section{Energy Availability of Steelworks and Direction for Improving}

The energy utilization rate in Japan is 34\%. ${ }^{3)}$ Energy utilization is defined as "the theoretical amount of energy requirement for a purpose divided by the amount of primary energy consumption to achieve it". In other words, an energy utilization rate of $34 \%$ means that about three times the amount of primary energy is used with respect to the theoretical amount of energy required for the purpose. It is necessary to obtain the energy we need in an energetically inexpensive way. ${ }^{4)}$ With this in mind, we first compared ways of using coal energy with other methods in terms of how they utilize reducing material, lighting, heat, and electric power at a steelworks to reduce $\mathrm{CO}_{2}$ emissions. Energy utilization in the case of fluid transport using coal-fired power generation and the case of coal being employed in an integrated steelworks are shown respectively in Figs. 1(a) and 1(b).

When comparing Figs. 1(a) and 1(b), since the power is not the end product, we compared the fluid transportation capable of using power most efficiently as the final end product. Moreover, for ease of comparison with Fig. 1(a), it was assumed that the steelworks in Fig. 1(b) is supplied entirely by coal.

According to Fig. 1(b), 33.5\% of the coal energy is used in the reduction reaction in the integrated steelworks, and $44 \%$ is recovered as by-product fuel gas. The recovered byproduct gas is used as fuel for heating furnaces inside the steel works and for power generation. The generated electric power and a portion of the by-product fuel gas are used to 


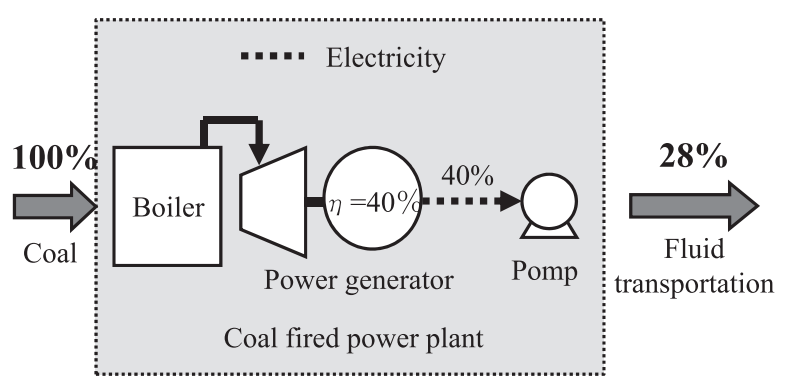

(a) Coal fired power generation

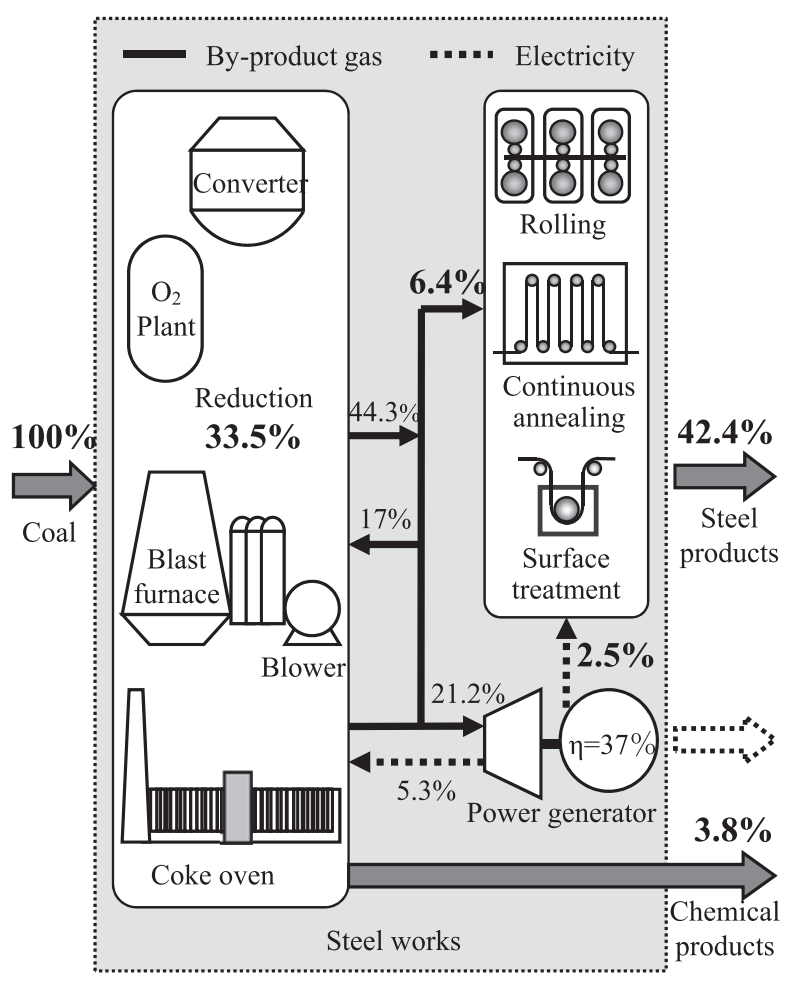

(b) Steel-making process

Fig. 1. Comparison between the energy availability in the case of coal fired power generation and Steel-Making process.

enhance the performance of rolling, annealing, plating, etc. In addition, volatile content included in the coke-oven gas becomes chemical products. As a result, the energy utilization rate of the steelworks reaches $46 \%(=33.5+6.4+2.5+3.8)$, which is 12 points higher than the national average of $34 \%$. On the other hand, according to Fig. 1(a) the energy utilization rate of the coal to power generation to fluid transportation process is $28 \%$, which is 6 points lower. Moreover, although for steel the object is the final product, the coalfired generation solely has value for the transportation of fluid. Since the energy utilization of the steel plant has value that includes energy for utility transport, such as that of cooling water for equipment, the difference between the energy utilizations of the two is huge.

The reason for the high energy utilization in the steelworks is apparent as in Fig. 1(b): the energy used for iron reduction is recovered and reused e.g. as by-product gas. With reference to Fig. 1(b), we can understand the directions towards and challenges of reducing $\mathrm{CO}_{2}$ emissions in a steelworks. The iron ore employed decides the heat of the reduction reaction, and there is a limit to reducing waste heat, which accounts for $18 \%(=100-(33.5+44.3+3.8))$. The by-product gas used as fuel comprises $44.3 \%$ of coal energy; generation and consumption are balanced. In the high-temperature reduction reaction using carbon as the reducing material in blast furnaces, the generation of by-product gas is reduced by decreasing the reducing material since it is difficult to significantly lower the $\mathrm{CO} / \mathrm{CO}_{2}$ ratio in blast furnace gas thermodynamically. As a result, it is necessary to newly purchase the required fuel and electric power for use inside the steel plants. Thus, in this case even decreasing the amount of reducing material in the blast furnace is not directly tied to the $\mathrm{CO}_{2}$ emissions reduction for the entire steelworks.

Accordingly, we focused on methods for utilizing this byproduct fuel gas. Summing the reduction reaction and the by-product gas generation, the conversion rate of energy from coal is very high at $77.5 \%$. In terms of $\mathrm{CO}_{2}$ emissions, one-third of the emissions of the entire steelworks is released from the blast furnace; two-thirds is emitted from power generators and heating equipment in the form of combustion exhaust within by-product gas. For the $\mathrm{CO}_{2}$ emissions comprising these two-thirds, the energy utilization rate for processes that enhance the performance of the manufactured product - such as rolling, annealing, plating, etc. - is at $20 \%(=(6.4+2.5) / 44) \times 100)$. This is 14 points lower than the domestic average energy utilization rate, and there is thought to be room for improvement. In other words, in an integrated steelworks utilizing the blast furnace method, energy utilization can be said to be high at upstream processes that generate by-product gas such as the blast furnace and coke oven, and low at downstream processes that make use of the generated by-product gas such as rolling and power generation. In order to increase the energy utilization rate of the steelworks as a whole, it is important to generate, recover, and supply the by-product gas as a fuel that can improve energy utilization on the usage side.

\section{Energy Recuperation from Steelworks to Society}

\subsection{Concept of Energy Recuperation}

As mentioned in Section 2, we cannot expect to improve the efficiency of the entire steelworks through reduction of the reducing materials and associated reduction of byproduct gas at upstream processes. Therefore, it is necessary to increase the utilization of by-product gas at downstream processes together with taking measures to reduce the exhaust heat and thus decrease the reducing materials in upstream processes. However, there is greater room for improvement at the low-efficiency downstream processes than at the high-efficiency upstream processes. For this reason, with progressive improvement of downstream processes, the energy recovery in upstream processes becomes greater than the energy consumption in downstream processes within the energy balance of the steelworks. In order to make good use of the surplus energy created by enhanced efficiency at downstream processes, instead of considering only the metrics of $\mathrm{CO}_{2}$ emissions and energy consumption at the narrow intra-steelworks boundary conditions, a new way of thinking that considers the boundary conditions of society as a whole is critical. One of those concepts is the social energy recuperation system to society shown in Fig. 2. 


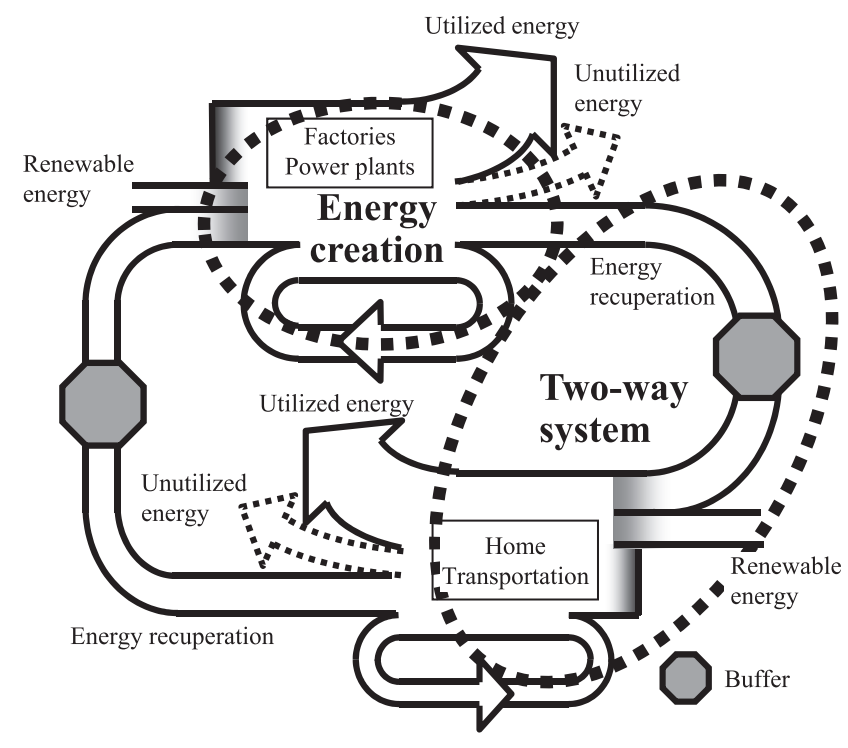

Fig. 2. A novel concept of social energy recuperation system.

A novel concept of social energy recuperation is a method of recovering and regenerating as much as possible of the highly valuable energy emitted from such processes and to supply it to society for re-use.

Considering the case of steelworks carrying out energy recuperation to society, the following two effects can be expected.

(1) For example, if the power generation efficiency rate at the steelworks in Fig. 1(b) shown previously can be increased to $55 \%$, power generation by coal of $3.8 \%$ $(=0.212 \times(0.55-0.37) \times 100)$ will be created after meeting the power demand of the steelworks. As for the coal-fired power generation in Fig. 1(a), this power is equivalent in effect to a reduction of coal consumption by about $10 \%(=3.8 /$ $40 \times 100)$.

(2) Where the energy recuperated from the steelworks to the society is electric power, the power generation cost can be inexpensive compared with using coal for the sole purpose of power generation, because power generation is carried out via by-product gas after coal is used for the reduction of iron ore. In this way, it is possible to reduce the electricity costs of society.

In other words, it is possible to simultaneously achieve $\mathrm{CO}_{2}$ reduction and reduction in social energy costs. In this manner, we will refer to a steelworks that combine the functions of energy supply to society and steel manufacturing by increasing their energy utilization of by-product gas as a hybrid steelworks.

\subsection{Study Method}

To clarify the effects of hybrid steelworks that have increased their energy utilization of by-product gas, we have considered and evaluated a hypothetical steelworks of 10 million $\mathrm{t} / \mathrm{y}$ of crude steel by using the steelworks energy balance simulation model shown in Fig. 3. ${ }^{4}$

The simulation model calculates the supply-and-demand energy balances of steam, fuel, and electric power for each process based on the input operating conditions, such as the amount of crude steel produced, the iron source, the type of energy to be used, and the thermal efficiency or reducing

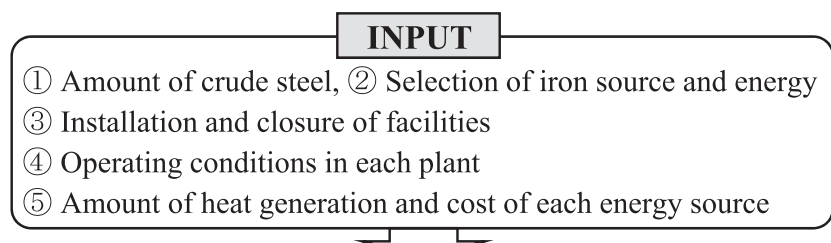

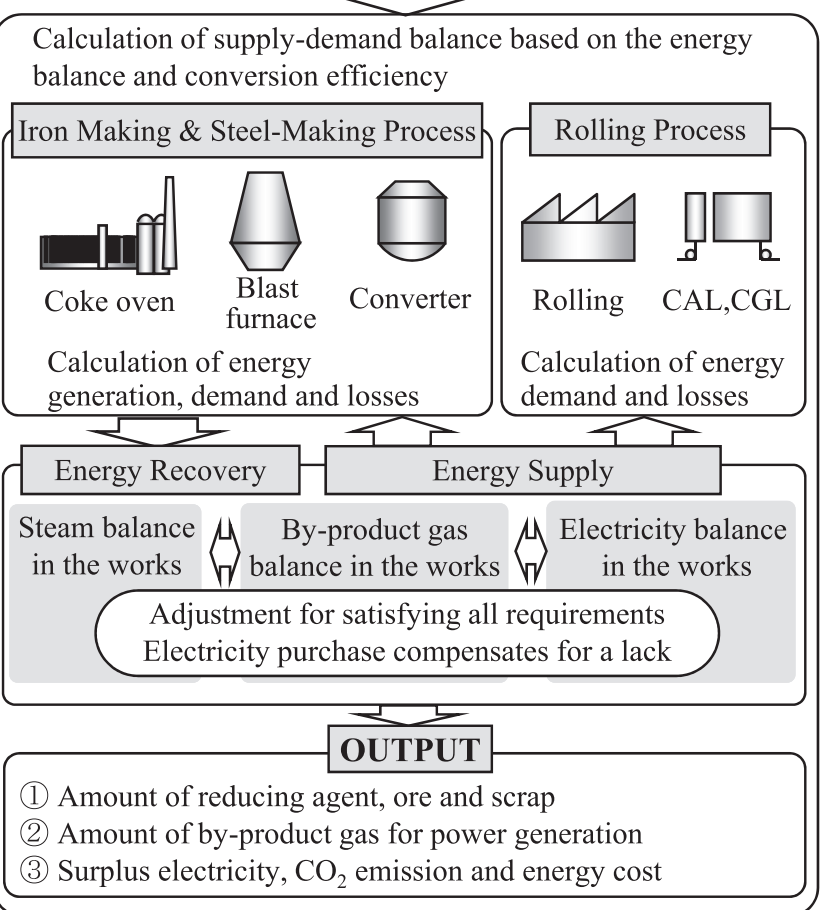

Fig. 3. Outline of the energy balance simulator in a steelworks.

materials ratio of each process. It calculates the energy balance of the overall steelworks as well as the type and balance of the required energy based on the supply-and-demand balances calculated for each process. The amounts of required energy, ore, scrap, power generated, $\mathrm{CO}_{2}$ emissions, etc. are outputted as the results.

As a calculated condition, either heavy oil or liquefied natural gas (LNG) have been employed as the fuel for calibrating the variation of the operational load, but in this study their consumption is a fixed value, and so we evaluated energy surplus and deficit in the steelworks in terms of electric power.

It should be noted that since the steel plant is under 24hour operation, the $\mathrm{CO}_{2}$ reduction effects of the electric power supplied by the steelworks; it is assumed that coalfired power generation would be stopped preferentially in order to lower them. The $\mathrm{CO}_{2}$ emissions factor was evaluated to be $0.864 \mathrm{~kg} / \mathrm{kWh}$.

\subsection{Case Studies and Calculated Conditions}

The following five cases were compared to evaluate their effects.

(1) Base case: A virtual steel plant that assumes current steelworks operations. The lower heating value (LHV) of blast furnace gas (hereafter referred to as $\mathrm{B}$ gas) is 3.1 $\mathrm{MJ} / \mathrm{m}_{\mathrm{N}}{ }^{3}$; its composition is $3 \% \mathrm{H}_{2}, 22 \% \mathrm{CO}, 22 \% \mathrm{CO}_{2}$, and $53 \% \mathrm{~N}_{2}$. The coke ratio is at $360 \mathrm{~kg} / \mathrm{t}$-pig given a reducing material ratio of $490 \mathrm{~kg} / \mathrm{t}$-pig, and the pulverized coal injection (PCI) ratio is $130 \mathrm{~kg} / \mathrm{t}$-pig. In addition, it uses $2.5 \times 10^{12}$ $\mathrm{kJ} /$ year of heavy oil in order to adjust fluctuation in by- 
product gas generation given a power generation efficiency of $37 \%$.

(2) Case 1: This case is conducted with energy conservation in the Base Case. Specifically: (1) By-product gas usage is reduced by $20 \%$ with the introduction of a regenerative heat exchange system ${ }^{6}$ into the rolling heating furnaces and annealing furnaces; (2) Electric power per unit of oxygen is reduced from 0.51 to $0.35 \mathrm{kWh} / \mathrm{O}_{2}-\mathrm{m}_{\mathrm{N}}{ }^{3}$ with the introduction of a high-efficiency oxygen plant; ;) (3) Coke ovens are replaced by SCOPE21 ${ }^{8,9)}$ (Super Coke Oven for Productivity and Environmental Enhancement toward the 21st Century); (4) Heavy oil is converted to LNG.

(3) Case2: In addition to Case 1 conditions: (5) With the introduction of the self-heat recuperative ${ }^{10)}$ amine process ${ }^{11)}$ to remove $\mathrm{CO}_{2}$ from $\mathrm{B}$ gas, (6) the source of the energy required for $\mathrm{CO}_{2}$ separation is provided by the steam recuperation method from thermal discharge of steelworks; ${ }^{12)}$ (7) The gas turbine combined cycle (GTCC) having 52.7\% power generation efficiency ${ }^{13)}$ is introduced alongside condition (5).

Regarding the separation energy for $\mathrm{CO}_{2}$, development has progressed in the COURSE50 project $^{14,15)}$ of an alkaline aqueous solution or absorbent, such as amine solution that keeps the required heat for amine regeneration below 2.0 $\mathrm{GJ} / \mathrm{t}-\mathrm{CO}_{2}$. However, this heat amount is the heat required to separate $\mathrm{CO}_{2}$ into a high purity suitable for underground storage. It is not necessary to carry out high-purity separation simply to increase the LHV. Also, in the case that the $\mathrm{CO}_{2}$ concentration in $\mathrm{B}$ gas rises to nearly $30 \%$ due to the removal of $\mathrm{N}_{2}$, the amount of heat required for the separation of $\mathrm{CO}_{2}$ per ton will decrease. Moreover, recent research of a self-heat recuperative amine process has reported that the required amount of heat can be reduced to less than $35 \%$ if self-heat recuperation technology is applied to the conventional amine method. ${ }^{10)}$ Therefore, it is considered that the amount of heat required for $\mathrm{CO}_{2}$ separation with the amine method can be $0.8 \mathrm{GJ} / \mathrm{t}-\mathrm{CO}_{2}$. As for the energy source for the anime method, it is possible to obtain hightemperature steam with $3 \mathrm{t} / \mathrm{h}$ of $150^{\circ} \mathrm{C}$ from $100 \mathrm{t}$ of $80^{\circ} \mathrm{C}$ thermal discharge of the steelworks. When the coefficient of performance (COP) is 5 , the power required for the generation of high -temperature steam is able to become 45 $\mathrm{kWh} / \mathrm{t}-\mathrm{CO}_{2}$. In addition, when the electric power required for amine solution circulation is $10 \mathrm{kWh} / \mathrm{t}-\mathrm{CO}_{2}$, the power required to separate $\mathrm{CO}_{2}$ from $\mathrm{B}$ gas enriched by $35 \% \mathrm{O}_{2}$ can be $55 \mathrm{kWh} / \mathrm{t}-\mathrm{CO}_{2}$.

The target quantity of $\mathrm{B}$ gas to separate $\mathrm{CO}_{2}$ is evaluated as only the B gas as power generation fuel for which effectiveness could be expected from the supply-and-demand balance of the steelworks B gas, coke oven gas (hereafter referred to as $\mathrm{C}$ gas), and converter gas. This is about twothirds of the $\mathrm{B}$ gas generated. Besides, without any underground storage, the separated $\mathrm{CO}_{2}$ is assumed to emit directly into the atmosphere.

(4) Case 3: The outline of the processes in this case is shown in Fig. 4.

From the figure, in addition to Case 2 conditions: (8) The $\mathrm{O}_{2}$ concentration of blown air is taken as $35 \%$ to remove $\mathrm{N}_{2}$ gas from the by-product gas (equivalent to removing $42 \%$ of $\mathrm{N}_{2}$ in the $\mathrm{B}$ gas); (9) PCI ratio is increased from 130 to $180 \mathrm{~kg} / \mathrm{t}$-pig accompanying this change while the reducing material ratio remains $490 \mathrm{~kg} / \mathrm{t}$-pig. LHV is $5.6 \mathrm{MJ} / \mathrm{m}_{\mathrm{N}}{ }^{3}$ for $\mathrm{B}$ gas after $\mathrm{N}_{2}$ and $\mathrm{CO}_{2}$ separation; along with this increase, the power generation efficiency of the GTCC is able to improve to $55.4 \%{ }^{13)}$

(5) Case 4: Case 3 is conducted with an increase in the reducing material ratio of the blast furnace. In order to evaluate the possibility of $\mathrm{B}$ gas production accompanying the increased reducing material ratio, this case was studied without consideration of blast furnace optimization, coordi-

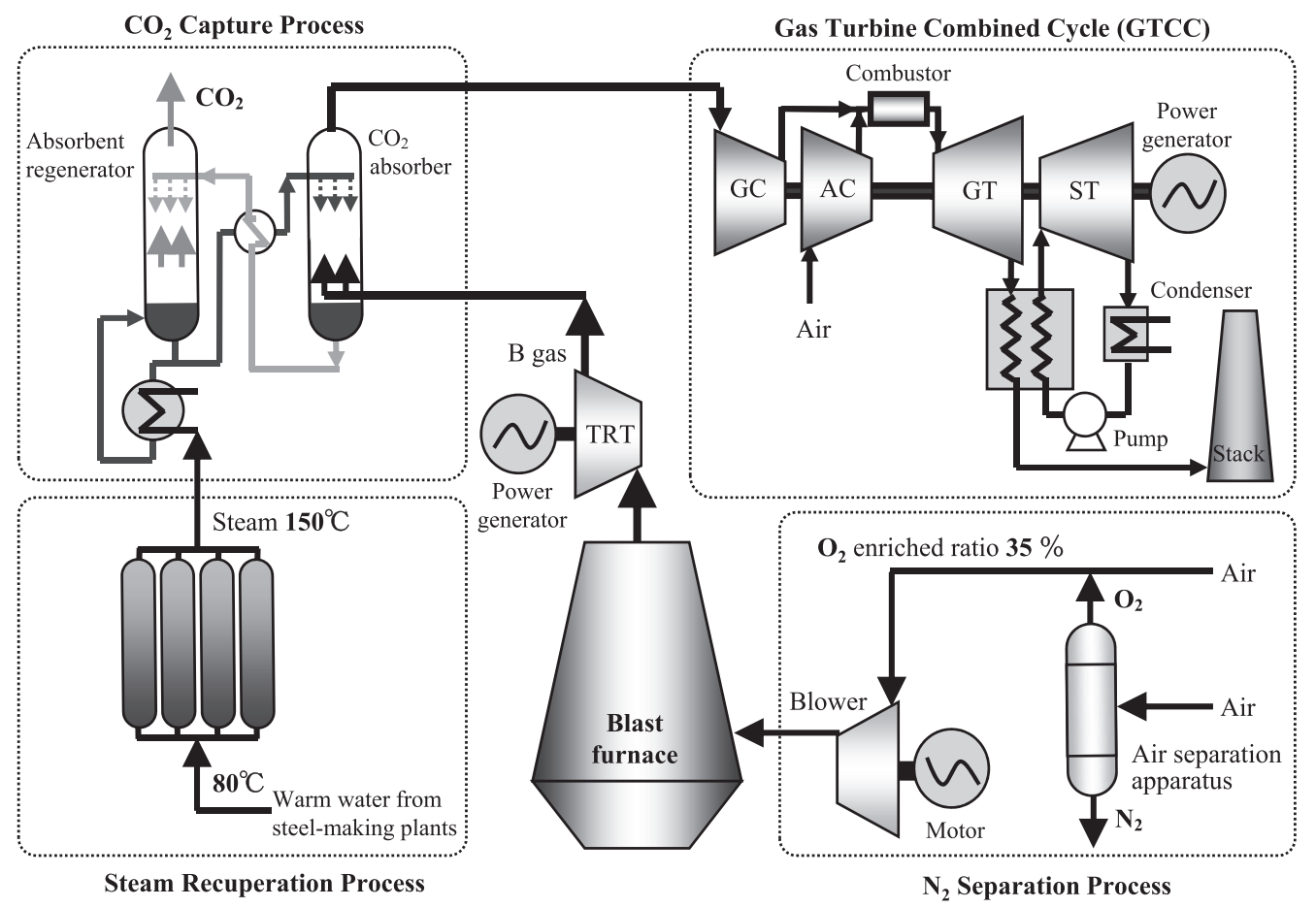

Fig. 4. Process system of the combined high efficiency GTCC with gas separation. 
nating only the heat balance of each processes, including of the blast furnace.

\section{Results of Case Studies}

The results of the Base Case are shown in Fig. 5.

From the figure, we see the generation and consumption of energy is balanced in the Base Case; there is no energy that can be supplied from the steel plant to the outside.

On the other hand, as shown in Fig. 6, it is possible in Case 1 to create surplus power of $7.6 \times 10^{8} \mathrm{kWh} /$ year accompanying the energy conservation in the steelworks.

In Fig. 6, the power supplied from existing power companies is reduced after appropriation of this created power into the domestic power demand, and the power generation fuel for existing coal-fired thermal energy decreases by $7.6 \times 10^{8} \mathrm{kWh} /$ year accordingly. It is calculated that a $\mathrm{CO}_{2}$ emissions reduction effect of 0.65 million $\mathrm{t}-\mathrm{CO}_{2} /$ year by using the $\mathrm{CO}_{2}$ emission factor of coal-fired thermal power; it becomes a reduction of 0.7 million $\mathrm{t}-\mathrm{CO}_{2} /$ year in total with the switching of heavy oil to $\mathrm{LNG}$. The $\mathrm{CO}_{2}$ reduction effectiveness of the steelworks becomes $3.6 \%$ ( $=0.7$ million $\left[\mathrm{t}-\mathrm{CO}_{2} /\right.$ year $] / 19.5$ million $\left[\mathrm{t}-\mathrm{CO}_{2} /\right.$ year $\left.] \times 100\right)$ under these considerations.

For Case 2, as shown in Fig. 7, although the power consumption increases to $2.6 \times 10^{8} \mathrm{kWh} /$ year to provide power for $\mathrm{CO}_{2}$ separation, introducing GTCC exerts a large effect, making surplus power production of $28 \times 10^{8} \mathrm{kWh} /$ year possible.

After the created power is appropriated into the domestic power demand, the fuel consumption for the coal-fired

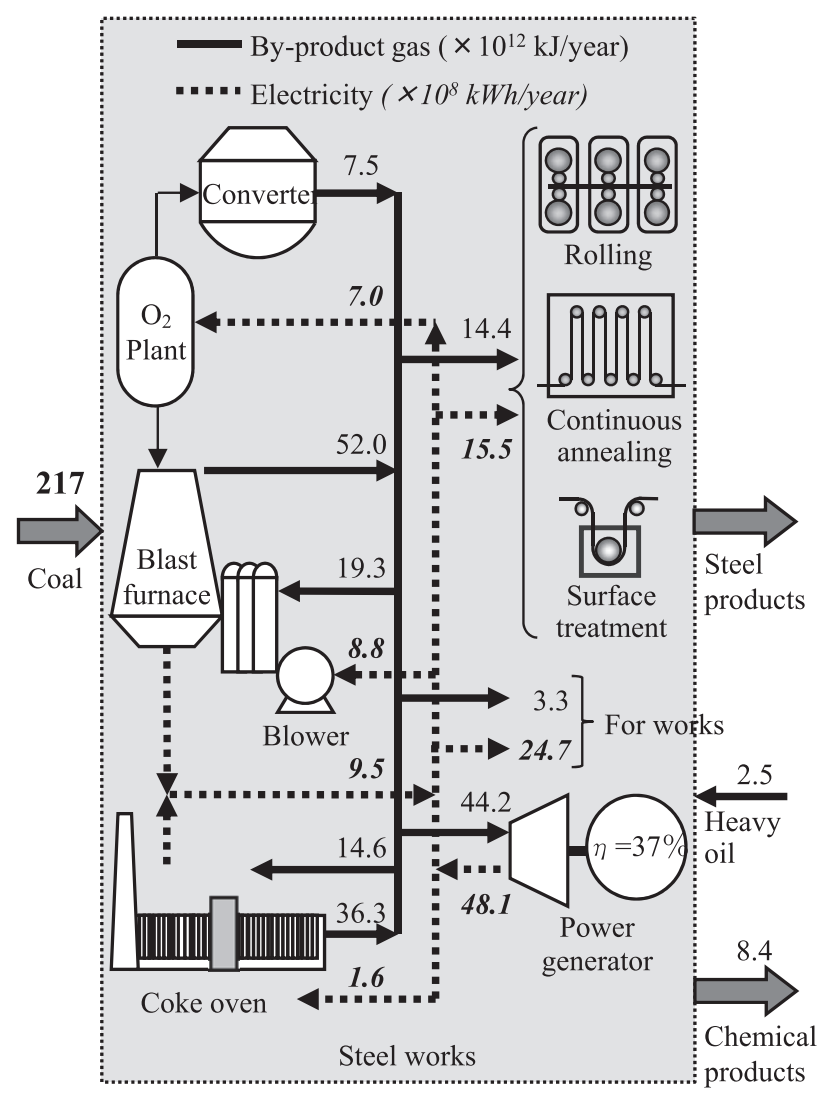

Fig. 5. Energy balance of a model steelworks in a base case. thermal power is reduced by an amount corresponding to power generation of $28 \times 10^{8} \mathrm{kWh} /$ year. As a result, the $\mathrm{CO}_{2}$ emissions of the nation as a whole will be reduced by 2.45

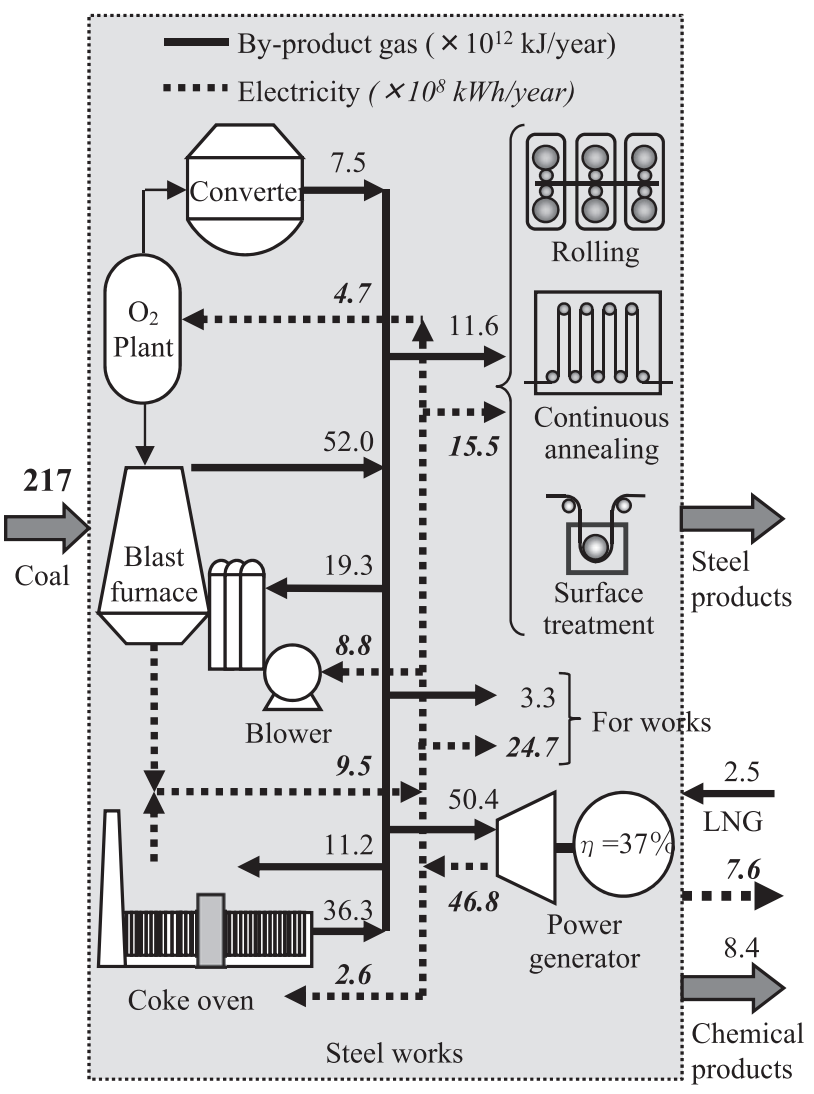

Fig. 6. Energy balance in Case1.

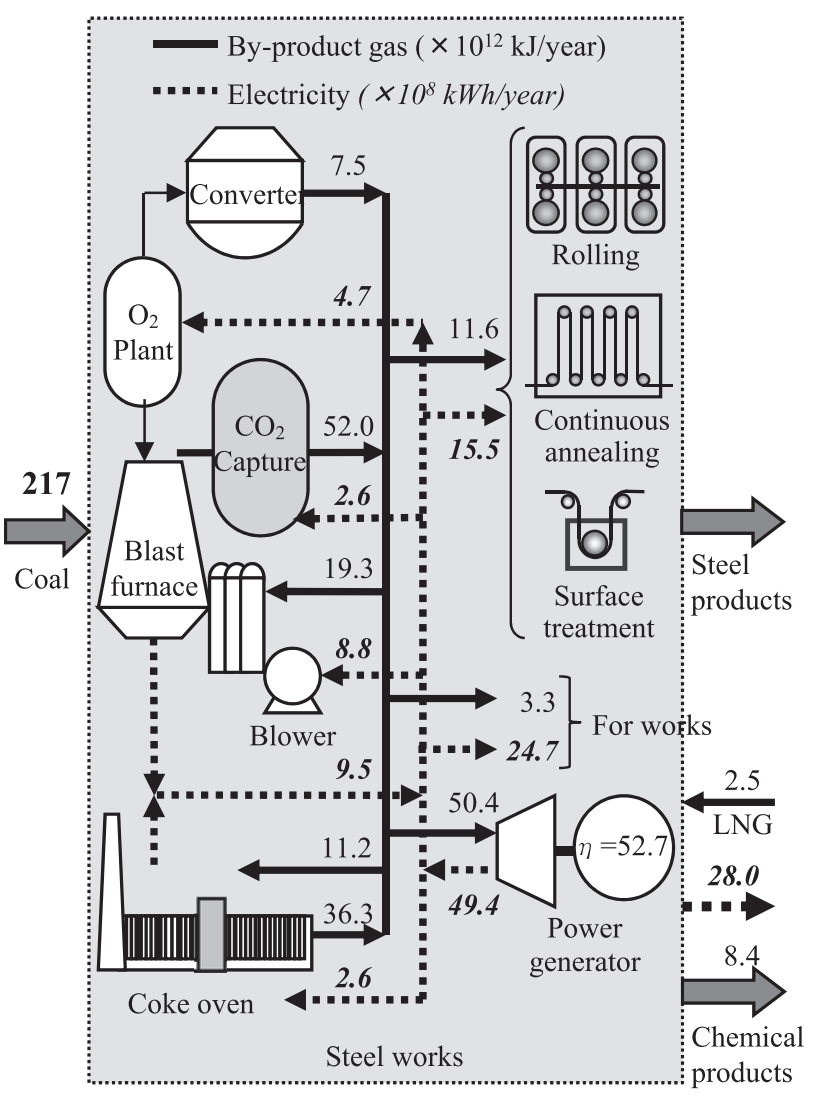

Fig. 7. Energy balance in Case2. 


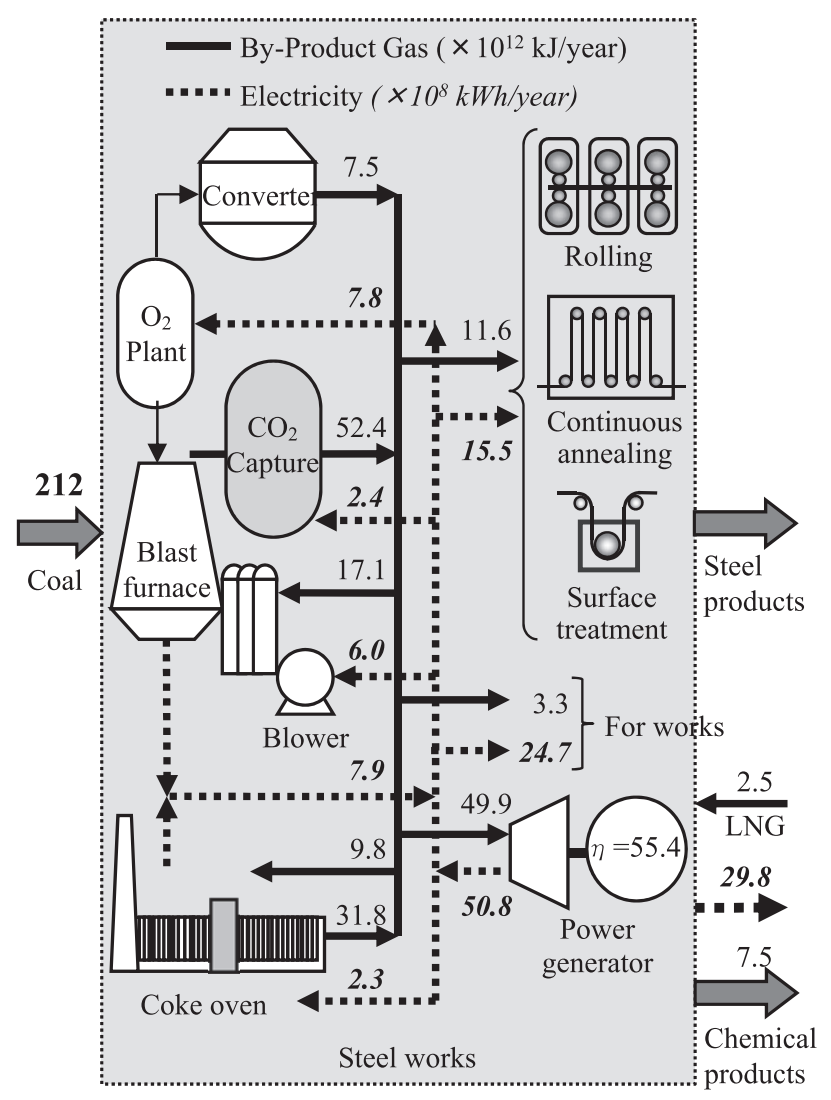

Fig. 8. Energy balance in Case3.

million $\mathrm{t}-\mathrm{CO}_{2} /$ year; the reduction becomes 2.5 million $\mathrm{t}$ $\mathrm{CO}_{2}$ /year in total with the switching of heavy oil to LNG. From this, the $\mathrm{CO}_{2}$ reduction effectiveness of the steelworks is as high as $12.8 \%\left(=2.5\right.$ million $\left[\mathrm{t}-\mathrm{CO}_{2} /\right.$ year $] / 19.5$ million $\left[\mathrm{t}-\mathrm{CO}_{2} /\right.$ year $\left.] \times 100\right)$ which is about three times more than for Case 1.

For Case3, as shown in Fig. 8, coal consumption is reduced due to oxygen enrichment by the blown air of the blast furnace and PCI ratio increase, and the power generation efficiency is able to improve from 52.7 to $55.4 \%{ }^{13)}$

However, because the decrease in $\mathrm{C}$ gas is large, the byproduct gas for power generation will also reduce, and because of the increased power demand of the steelworks, the surplus power becomes about $30 \times 10^{8} \mathrm{kWh} /$ year. In total with the switching of heavy oil to $\mathrm{LNG}$, the reduction of $\mathrm{CO}_{2}$ becomes 2.65 million $\mathrm{t}-\mathrm{CO}_{2} /$ year, and the reduction in coal consumption results in another 0.5 million $\mathrm{t}-\mathrm{CO}_{2} /$ year, equaling 3.15 million $\mathrm{t}-\mathrm{CO}_{2} /$ year in total. Accordingly, the $\mathrm{CO}_{2}$ reduction effectiveness of the entire steelworks becomes $16.2 \%\left(=3.15\right.$ million $\left[\mathrm{t}-\mathrm{CO}_{2} /\right.$ year $] / 19.5$ million $\left[\mathrm{t}-\mathrm{CO}_{2} /\right.$ year $\left.] \times 100\right)$.

Since in the examination results thus far the effective $\mathrm{CO}_{2}$ emissions deduction is huge due to the surplus power borne from the increased power generation, we examine Case 4, in which the reducing material ratio is increased. The results are shown in Fig. 9.

In Fig. 9, the amount of by-product gas for power generation will increase by a factor of more than 1.1 , and the total power generation becomes $99 \times 10^{8} \mathrm{kWh} /$ year. The surplus power becomes $39.4 \times 10^{8} \mathrm{kWh} /$ year, and the effective $\mathrm{CO}_{2}$ reduction via power creation becomes 3.1 million $\mathrm{t}-\mathrm{CO}_{2} /$ year less than Case 3, because although it becomes 3.45 mil-

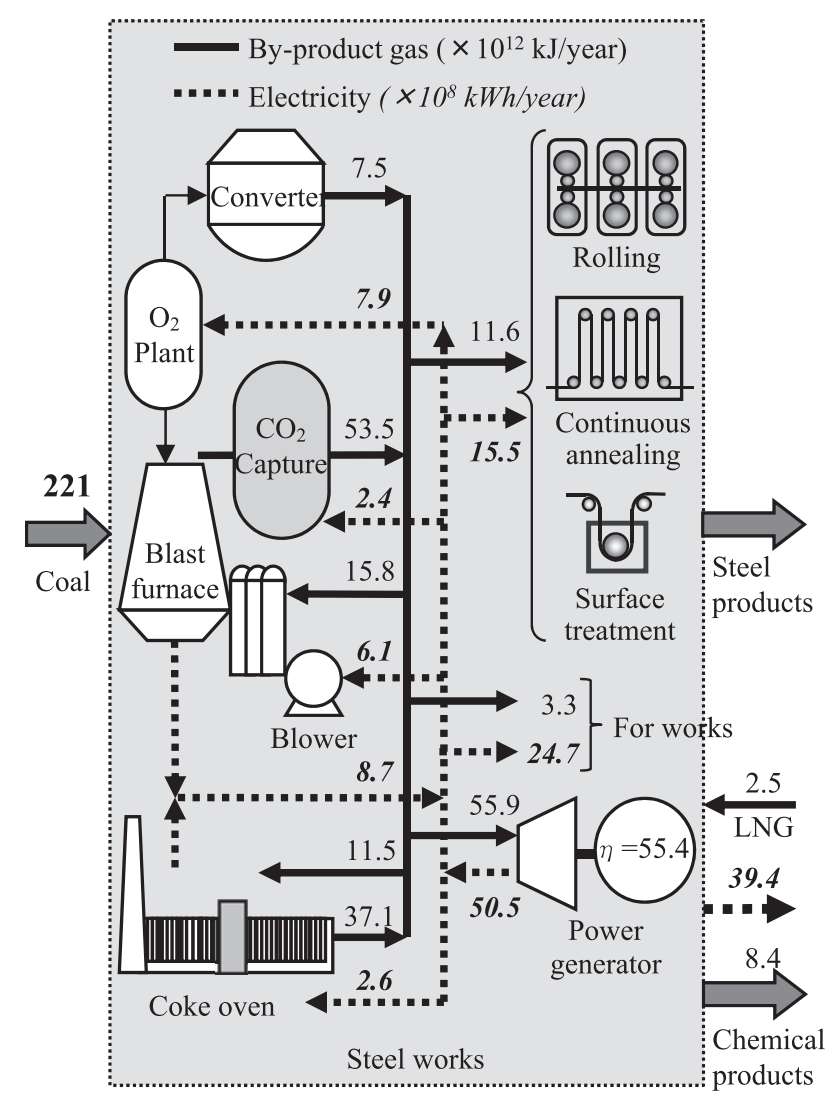

Fig. 9. Energy balance in Case4.

lion $\mathrm{t}-\mathrm{CO}_{2} /$ year after switching from heavy oil to $\mathrm{LNG}$, the amount from coal increases by 0.35 million $\mathrm{t}-\mathrm{CO}_{2} /$ year.

\section{Discussion}

The results of the case studies are summarized in Tables 1 and 2.

Table 1 is shown as the results of comparing the energy conservation and improvement in power generation efficiency in the steelworks. Table 2 is shown as the effects of the increasing of the reducing material.

From Table 1, the power generation efficiency in Case 1 is low even though surplus by-product gas is created by energy conservation of the steelworks, and we cannot fully benefit from its effects. Moreover, since a large deduction is caused by the surplus power, it is clarified that the method of creating surplus power using efficiently generated byproduct gas is very effective in the steelworks, where it is difficult to lower the $\mathrm{CO} / \mathrm{CO}_{2}$ ratio of $\mathrm{B}$ gas using a blast furnace process.

On the other hand, from Table 2, for the method in Case 4 of increasing the reducing material and thus the amount of power generation, the total reduction in $\mathrm{CO}_{2}$ emissions is smaller than the rise in surplus power such as Case 3. For the reason, since the coal by-product gas conversion rate is approximately $70 \%$ which is calculated by comparing two Case 3 and Case 4, the overall efficiency in the steelworks for the coal to by-product gas to power generation process is $38.8 \%(=0.7 \times 0.554 \times 100)$. Because this efficiency is almost the same as that of coal-fired power generation, the $\mathrm{CO}_{2}$ emissions reduction is not connected with efficiency in the methodology of the increased reducing material. In order 
Table 1. Effect of improvement of energy utilization efficiency and power generation efficiency.

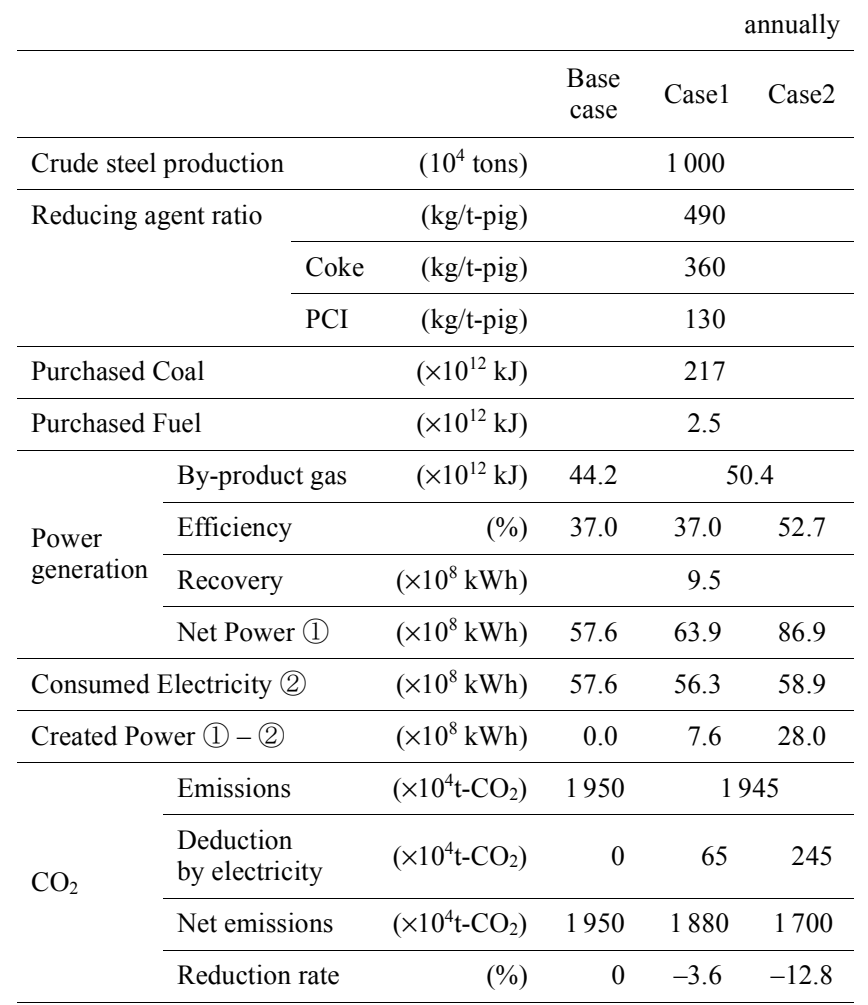

Note) The $\mathrm{CO}_{2}$ emission unit for the surplus electricity is evaluated by the base coal-fired power generation $\left(0.864 \mathrm{~kg}-\mathrm{CO}_{2} / \mathrm{kWh}\right)$.

to achieve higher efficiency than existing coal-fired power generation, the by-product gas conversion efficiency from coal must be above $72.2 \%(=0.4 / 0.554 \times 100)$.

The relatively simplified cases are shown in this study, but if it is increased the LHV of blast furnace gas by introducing further $\mathrm{O}_{2}$ enrichment into the blast furnace, and increased the by-product gas generation without increasing the amount of reducing material, the effect of hybrid steelworks is able to be expand. For example, if the sensible exhaust heat of the steelworks will be recovered as combustion heat of the by-product gas through the use of the endothermic reaction when $\mathrm{C}_{\mathrm{n}} \mathrm{H}_{\mathrm{m}}$ contained in the coke oven gas thermally decomposes, the total combustion heat can be 1.3 times greater than that of the original coke oven gas. ${ }^{16)}$ If this is used in power generation, an additional 1.5 billion $\mathrm{kWh} /$ year of power will be created from Fig. 8. Accordingly, a further 1.3 million $\mathrm{t}-\mathrm{CO}_{2} /$ year will be reduced by the whole country, which is equivalent to a $23 \%(=(16.35-1.30)$ million $\left[\mathrm{t}-\mathrm{CO}_{2} /\right.$ year $] / 19.5$ million $\left[\mathrm{t}-\mathrm{CO}_{2} /\right.$ year $\left.] \times 100\right) \mathrm{CO}_{2}$ emissions reduction by the steelworks.

As the results, the power of 4.5 billion $\mathrm{kWh} / \mathrm{year}$ is able to create by a steelworks with crude steel production of 10 million t-steel/year that applies a GTCC for gas separation. By converting all steel plants in the country ( 84 million tsteel/year blast furnace crude steel) ${ }^{17)}$ it has a potential that the power of 38 billion $\mathrm{kWh} /$ year $(=4.5$ billion $[\mathrm{kWh} /$ year] $\times$ 84 million [t-steel/year] $/ 10$ million [t-steel/year]) is able to be generated. This creating power accounts for $4.0 \%$ of gross domestic power demand ( $=38$ billion $[\mathrm{kWh} /$ year] $\times$ 94.1 billion $\left[\mathrm{kWh} /\right.$ year ${ }^{18)} \times 100$ ), which is equivalent to six nuclear power plants. If this created power is substituted for
Table 2. Effect of increase in reducing material.

\begin{tabular}{|c|c|c|c|c|c|c|}
\hline & & & & $\begin{array}{l}\text { Base } \\
\text { case }\end{array}$ & Case3 & Case 4 \\
\hline \multicolumn{3}{|c|}{ Crude steel production } & ( $10^{4}$ tons) & & 1000 & \\
\hline \multirow{3}{*}{\multicolumn{2}{|c|}{ Reducing agent ratio }} & & (kg/t-pig) & 490 & 490 & 500 \\
\hline & & Coke & (kg/t-pig) & 360 & 310 & 370 \\
\hline & & PCI & (kg/t-pig) & 130 & 180 & 130 \\
\hline \multicolumn{3}{|c|}{ Purchased Coal } & $\left(\times 10^{12} \mathrm{~kJ}\right)$ & 217 & 212 & 221 \\
\hline \multirow{5}{*}{$\begin{array}{l}\text { Power } \\
\text { generation }\end{array}$} & \multicolumn{2}{|c|}{ Purchased Fuel } & $\left(\times 10^{12} \mathrm{~kJ}\right)$ & \multicolumn{3}{|c|}{2.5} \\
\hline & \multicolumn{2}{|c|}{ By-product gas } & $\left(\times 10^{12} \mathrm{~kJ}\right)$ & 44.2 & 49.9 & 55.9 \\
\hline & \multicolumn{2}{|c|}{ Efficiency } & $(\%)$ & 37.0 & \multicolumn{2}{|c|}{55.4} \\
\hline & \multicolumn{2}{|l|}{ Recovery } & $\left(\times 10^{8} \mathrm{kWh}\right)$ & 9.5 & 7.9 & 8.7 \\
\hline & \multicolumn{2}{|c|}{ Net Power (1) } & $\left(\times 10^{8} \mathrm{kWh}\right)$ & 57.6 & 88.5 & 98.6 \\
\hline \multicolumn{3}{|c|}{ Consumed Electricity (2) } & $\left(\times 10^{8} \mathrm{kWh}\right)$ & 57.6 & 58.7 & 59.2 \\
\hline \multicolumn{3}{|c|}{ Created Power (1) - (2) } & $\left(\times 10^{8} \mathrm{kWh}\right)$ & 0.0 & 29.8 & 39.4 \\
\hline \multirow{4}{*}{$\mathrm{CO}_{2}$} & \multicolumn{2}{|c|}{ Emissions } & $\left(\times 10^{4} \mathrm{t}-\mathrm{CO}_{2}\right)$ & 1950 & 1895 & 1980 \\
\hline & \multicolumn{2}{|c|}{$\begin{array}{l}\text { Deduction } \\
\text { by electricity }\end{array}$} & $\left(\times 10^{4} \mathrm{t}-\mathrm{CO}_{2}\right)$ & 0 & 260 & 340 \\
\hline & \multicolumn{2}{|c|}{ Net emissions } & $\left(\times 10^{4} \mathrm{t}-\mathrm{CO}_{2}\right)$ & 1950 & 1635 & 1640 \\
\hline & \multicolumn{2}{|c|}{ Reduction rate } & $(\%)$ & 0 & -16.2 & -15.9 \\
\hline
\end{tabular}

Note) The $\mathrm{CO}_{2}$ emission unit for the surplus electricity is evaluated by the base coal-fired power generation $\left(0.864 \mathrm{~kg}-\mathrm{CO}_{2} / \mathrm{kWh}\right)$.

current coal-fired power, it is able to expect a $\mathrm{CO}_{2}$ emissions reduction of 33 million $\mathrm{t}-\mathrm{CO}_{2} /$ year. Moreover, this power generation from the steelworks does not increase in additional fuel consumption, and its costs depend on equipment investment. Thus, it is possible to supply the power to the society with quite inexpensively.

The following are important future directions for reducing $\mathrm{CO}_{2}$ emissions through the use of hybrid steelworks as a society.

(1) Improvement of coal by-product gas conversion efficiency

It is important to reduce the reducing material ratio without reducing the total heat generation of the by-product gas, or to generate by-product gas at as high conversation efficiency above $72.2 \%$ when the quantity of reducing material is increased.

(2) Improvement of by-product gas energy availability

In this study, it is discussed that methodologies using the difference of energy conversion efficiency such as the power generation between in the steelworks and in the power companies. In any other way, in order to increase the energy utilizing efficiency of the society, it is important to evaluate the difference of the total energy conversion efficiency such as medium for supplying energy between electricity and $\mathrm{H}_{2}$.

(3) Promotion of energy conservation in steelworks

It is necessary to increase the energy supply for outside the steelworks. The energy supply is increased by the reduction of electricity and fuel consumption of the facilities in the steelworks. The latter increases the available by-product gas to power generation.

As for specific methods to achieve (1) through (3) above, 
it is important to develop technology that makes use of separated $\mathrm{CO}_{2}$, high PCI values, high concentrations of oxygen enrichment in the blown air of the blast furnace and fuel recuperation by sensible heat via e.g. the thermal decomposition of $\mathrm{C}$ gas.

\section{Conclusion}

A hybrid steelworks having functionality that combines steel manufacturing and energy supply is proposed, focusing on improving the energy utilization of by-product gas based on the energy balance of steelworks. It has been examined that the effects of the energy and $\mathrm{CO}_{2}$ emissions reductions by the hybrid steelworks on society. The results is as follows:

The steelworks possesses a high energy utilization rate, since it recovers and reuses the coal energy used in the reduction reaction in the form of by-product gas.

The typical hybrid steelworks is able to supply society with low-cost electric power without increasing energy consumption through the use of combined high-efficiency GTCC with the promotions of energy conservation in steelworks such as $\mathrm{CO}_{2}$ and $\mathrm{N}_{2}$ separation in blast furnace gas.

Moreover, if the technology of this hybrid steelworks is applied to all steelworks in Japan (84 million t-steel/year blast furnace crude steel), the power generation potential is more than 38 billion $\mathrm{kWh} /$ year which is equivalent to $4.0 \%$ of gross domestic power demand. Furthermore, a $\mathrm{CO}_{2}$ reduction of 33 million $\mathrm{t}-\mathrm{CO}_{2} /$ year nationally can be expect- ed; this effect is equivalent to a $23 \%$ reduction in steelworks $\mathrm{CO}_{2}$ emissions.

\section{REFERENCES}

1) Ministry of Finance Japan: Trade Statistics of Japan for 2013 (2014), http://www.customs.go.jp/toukei/shinbun/trade-st/2013/2013_214.pdf, (accessed 2014-04-22).

2) SMART Study Group: Small Advanced Regional Energy Technology, Kaibundo, Tokyo, (2004), 131.

3) K. Hirata: Handout for RC185, The Japan Society of Mechanical Engineers, Tokyo, (2001).

4) T. Nakagawa: J. Jpn. Soc. Energ. Resources, 32 (2011), No. 4, 1.

5) E. Imamura and K. Nagano: Socio-economic Res. Center Rep., No.Y09027, (2010), 9.

6) T. Nakagawa and N. Arai: Kagaku Kogaku Ronbunshu, 26 (2000), 236.

7) K. Haruna, M. Miyake and H. Sasano: Sumitomo Kagaku $R \& D$ Report, 2 (2005), 59.

8) K. Nishioka, H. Oshima, I. Sugiyama and H. Fujikawa: Tetsu-toHagané, 90 (2004), 614.

9) K. Kato: J. Jpn. Inst. Energy, 89 (2010), 2

10) K. Kishimoto: Doctoral Dissertations of Tokyo Univ., (2012).

11) T. Mimura, M. Hayashi and D. Hagiu: Nippon Steel Eng. Co., Ltd. Tech. Rev., 3 (2012), 25.

12) K. Nakaso, E. Oktariani, A. Noda, Y. Itaya, T. Nakagawa and J. Fukai: J. Jpn. Soc. Energ. Resources, 32 (2011), No. 5, 9.

13) T. Nakagawa: Trans. JSME Ser. B, 78 (2012), 1560.

14) COURSE50, http://www.jisf.or.jp/course50/outline/, (accessed 201404-25).

15) T. Miwa and H. Okuda: J. Jpn. Inst. Energy, 89 (2010), 28.

16) T. Shikata, H. Yatabe, N. Meguri and K. Matsuyama: Sekitann Kagaku Kaigi Happyou Ronbunshu, 45 (2008), 46.

17) World steel Annual Production 2013: The Japan Iron and Steel Federation, Tokyo, (2014), http://www.jisf.or.jp/en/statistics/IISI/ index.html, (accessed 2014-04-25).

18) Generation Electric Energy Composition Ratio According to Power Supply: The Federation of Electric Power Companies of Japan, Tokyo, (2013), http://www.fepc.or.jp/about_us/pr/sonota/_icsFiles/ afieldfile/2013/05/17/kouseihi 2012.pdf, (accessed 2014-04-25). 